АНАЛІЗ МОЖЛИВОСТЕЙ ТВОРЧОГО ВИКОРИСТАННЯ В УКРАЇНІ

\author{
ПРАКТИЧНИХ ДОРОБОК 3 ФОРМУВАННЯ ПРОФЕСІЙНОЇ \\ КОМПЕТЕНТНОСТІ МАЙБУТНІХ УЧИТЕЛІВ МУЗИЧНОГО МИСТЕЦТВА \\ В КИТАЙСЬКІЙ ВИЩІЙ ШКОЛІ
}

\title{
THE ANALYSIS OF POSSIBLE CREATIVE APPLICATION OF PRACTICAL WORKS ON VOCATIONAL COMPETENCE FORMATION OF FUTURE MUSICAL ART TEACHERS IN CHINESE HIGHER SCHOOL INTO UKRAINIAN SCHOOL
}

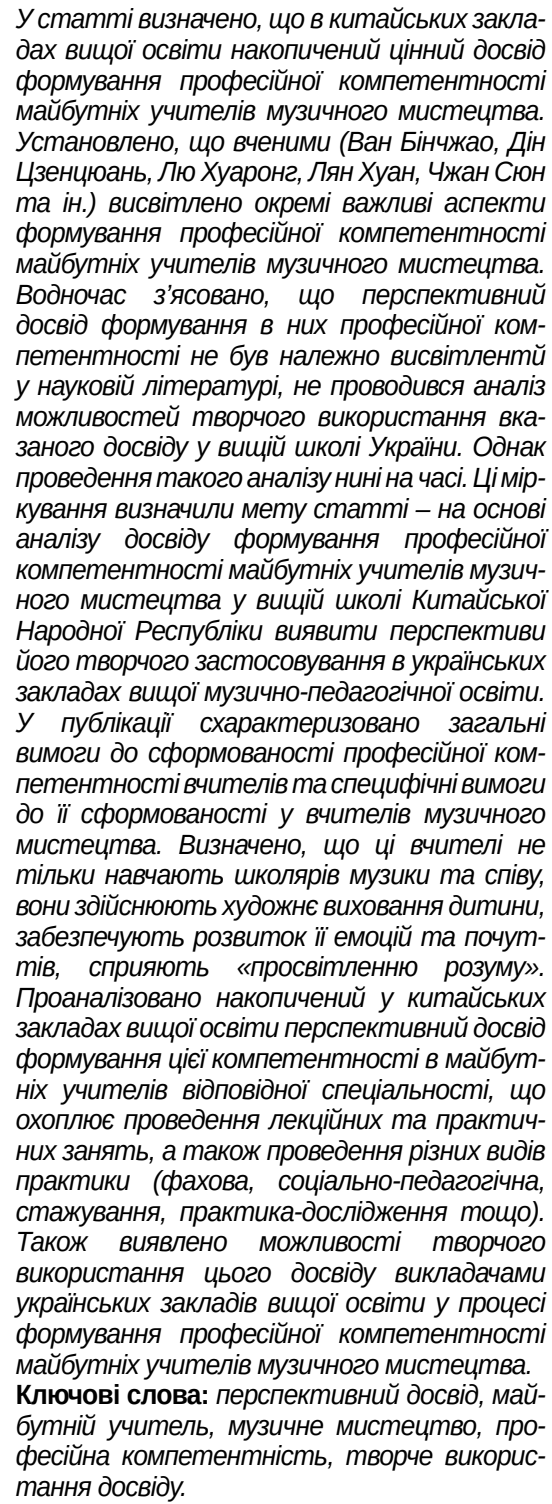
DOI https://doi.org/10.32843/26636085/2020/25-1.2

\section{Джоу Юнь}

аспірантка кафредри педагогіки

Харківського національного

педагогічного університету

імені Г.С. Сковороди
The article states that Chinese higher education institutions have accumulated valuable experience in the vocational competence formation of future musical art teachers. It was found out that scientists and scholars such as Wang Bingzhao, Din Gzhenquan, Liu Harong, Liang Huang, Zhang Xiong and others highlighted some important aspects of vocational competence formation of future musical art teachers. At the same time, it was found out that the promising experience of vocational competence formation has not been adequately researched in the scientific works, the analysis of the possibilities of creative application of the experience in higher education in Ukraine has not been conducted yet. However, such analysis is urgent and necessary for modern Ukrainian School. These considerations determined the purpose of the article, that is based on the analysis of the experience of vocational competence formation of future musical art teachers in higher education in China to identify prospects for its creative application in Ukrainian institutions of higher music education.

The general requirements for the teachers vocational competence formation and specific requirements for its formation among musical art teachers have been characterized in the article. It is determined that these teachers not only teach students music and singing, but they also carry out the child's artistic education as well as they ensure the development of the child's emotions and feelings, contributing to the "enlightenment of the mind". The accumulated promising experience on this competence formation among future teachers of the relevant specialty, including lectures and practical classes, as well as conducting various types of practice (professional, sociopedagogical, internship, research practice, etc.) in higher education Chinese institutions have been studied. The possibilities of creative use of this experience by teachers of Ukrainian higher education institutions in the process of vocational competence formation of future musical art teachers are also revealed.

Key words: promising experience, future teacher, musical art, vocational competence, creative application of experience.
Постановка проблеми в загальному вигляді. Результатом інтеграції вищої освіти Китайської Народної Республіки у світовий освітній простір $€$ активне рефрормування освітньої системи на засадах компетентнісного підходу. У контексті необхідності забезпечення відповідності професійної підготовки музичнопедагогічних кадрів сучасним світовим вимогам у китайських закладах вищої освіти відбувається цілеспрямоване формування професійної компетентності в майбутніх учителів музичного мистецтва. Оскільки в китайській вищій школі накопичено цінний практичний досвід 3 окресленого питання, виникає актуальна потреба в його всебічному аналізі та виявленні можливостей творчого застосування в українських закладах вищої освіти.

Аналіз останніх досліджень і публікацій. Дані проведених наукових розвідок засвідчують, що вченими було висвітлено такі важливі аспекти фрормування профресійної компетентності майбутніх учителів музичного мистецтва: 
- розкрито ретроспективу розвитку музичного мистецтва в Китаї (Ван Бінчжао, Сун Пенцин, Чжан Сюн, Чжан Хао й ін.);

- обґрунтовано наукові й методичні засади організації та реалізації музично-педагогічної освіти в Китайській Народній Республіці (Ван Бін, Вей Лімінь, Дін Цзенцюань, Ло Чао, Лян Хуан, ші Вейчжен та ін.);

- проаналізовано суть профресійної компетентності майбутніх учителів музичного мистецтва та сучасні вимоги до їі фрормування (Вей Тінге, Лінь Хуацінь, Лю Хуаронг, Чжан Сянюн та ін.).

Виділення не вирішених раніше частин загальної проблеми. Науковці зробили вагомий внесок у вивчення порушеної проблеми. Проте результати проведеного наукового пошуку засвідчують, що перспективний досвід формування профресійної компетентності в майбутніх учителів музичного мистецтва не був належно висвітлений у науковій літературі. Крім того, дослідниками не проводився аналіз можливостей творчого використання цього досвіду у вищій школі України. Однак проведення такого аналізу нині на часі, бо творче застосування накопичених китайськими педагогами практичних доробків із досліджуваної проблеми українськими викладачами під час профресійної підготовки майбутніх учителів музичного профілю дозволило б значно підвищити ефрективність цього процесу.

Мета статті - на основі аналізу досвіду формування професійної компетентності майбутніх учителів музичного мистецтва у вищій школі Китайської Народної Республіки (далі - КНР) виявити перспективи його творчого застосовування в українських закладах вищої музичнопедагогічної освіти.

Виклад основного матеріалу. Під час проведення дослідження встановлено, що у 2015 р. опубліковано «Керівництво до визначення профресійних стандартів учителів КНР», у якому визначено основні стандарти - показники сформованості педагогічної компетентності у шкільних педагогів. Ці показники були основними орієнтирами в організації професійної підготовки майбутніх учителів усіх спеціальностей і оцінюванні результатів їі здійснення протягом усієї наступної п'ятирічки (2016-2020 рр.).

Так, відповідно до змісту цього документа, основні показники сорормованості професійної компетентності шкільного педагога такі:

- володіння необхідними знаннями про суть, цілі, цінності шкільної освіти та вимоги щодо ії здійснення;

- наявність спеціальних знань і вмінь у царині обраної спеціальності;

- висока обізнаність щодо змісту навчальних програм, уміння розробляти індивідуальні навчальні плани для школярів;
- уміння реалізовувати авторські стратегії викладання навчальних предметів на основі вивчення особливостей та потреб учнів, володіння інноваційними освітніми технологіями;

- опанування різних методів оцінювання навчальних досягнень школярів, навичок супроводжувати виставлення відміток аналітичними коментарями, що сприяє навчанню учнів здійснювати об'єктивне самооцінювання результатів своєї навчальної діяльності;

- уміння створювати доброзичливу атмосферу у класі, сприятливе освітнє середовище;

- уміння виявляти фронові індивідуальні характеристики школярів, готовність проявляти повагу до кожного з них, оптимальним способом використовувати наявні освітні й інші ресурси;

- готовність дотримуватися законів і нормативних актів у галузі шкільної освіти, сумлінно реалізовувати свої професійні функції й обов'язки;

- наявність прагнення та готовності здійснювати постійний профресійний розвиток, своєчасно виявляти вади у своїй роботі та швидко їх виправляти;

- готовність активно співпрацювати з усіма учасниками освітнього процесу (школярі, інші вчителі, батьки та представники громадськості) [5, с. 3-6 ].

У світлі вивчення порушеної проблеми важливо відзначити, що під час фрормування профресійної компетентності майбутніх учителів музичного мистецтва китайські викладачі орієнтуються не тільки на загальні вимоги до підготовки сучасних учителів, але й на специфічні вимоги щодо підготовки педагогів указаного профрілю. У світлі цього профресор Шандуського педагогічного університету Лю Донгюн наголошує, що вчитель музичного мистецтва має не тільки навчати учнів музиці та співу. Він повинен здійснювати художнє й естетичне виховання кожної особистості, розвивати іï емоційну сореру, забезпечувати «просвітлення розуму». Тому студенти музично-педагогічних спеціальностей мають на високому рівні опанувати професійно важливі знання, уміння, якості як для педагога, так і для музиканта та співака [6].

Як з'ясовано, навчальний план підготовки майбутніх учителів музичного мистецтва включає теоретичну і практичну складові частини та передбачає викладання студентам загальноосвітніх, педагогічних та музично орієнтованих навчальних дисциплін. Водночас підвищення рівня профресійної компетентності майбутніх педагогів відбувається шляхом раціонального поєднання традиційних та інноваційних моделей, методів та форм навчання. Зокрема, для студентів проводять як традиційні теоретичні та практичні заняття, так і заняття нового типу, які поєднують у собі теоретичні та практичні аспекти (наприклад, імпровізований музичний супровід, візуальний спів, хорове диригування тощо). У процесі навчання широко застосовують також різні інфрормаційні, зокрема 
й музично-комп'ютерні, технології, які не тільки підвищують якість вищої освіти, але і дозволяють майбутнім учителям музичного мистецтва набувати досвіду використання цих технологій у процесі навчання, що дасть змогу пізніше використовувати цей досвід у роботі з учнями.

Чільне місце у процесі формування профресійної компетентності в цих фахівців також посідає виробнича практика. У вищій школі КНР студенти проходять різні її види: фрахову практику, соціально-педагогічну практику, практику-стажування, практику-дослідження тощо.

Так, фахова практика включає відвідування студентами концертів та набуття власного досвіду виконавської інструментальної й вокальної діяльності.

Соціально-педагогічна практика дає змогу майбутнім учителям отримати досвід практичної педагогічної діяльності у школах та здійснення різних видів суспільно корисної діяльності. Зокрема, студенти безкоштовно виступають із концертами у віддалених бідних сільських районах та навчають місцевих дітей музики, вокального та хорового співу. Студенти також створюють практико-зорієнтовані дослідницькі проєкти, присвячені вивченню різних актуальних професійно-педагогічних проблем [6].

Як зазначають китайські науковці (Ду Сивей, Лі Данься, Яо Вей та ін.), фрормування професійної компетентності майбутніх учителів музичного мистецтва в китайських закладах вищої музичної та музично-педагогічної освіти характеризується нині такими особливостями:

- застосування різних стилів виконавського музичного та пісенного мистецтва, які тісно взаємодіють один з одним;

- прояв у процесі здійснення професійної підготовки вокалістів та вчителів співу тенденції до стилістичної комбінаторики (тобто поєднання академічного, народного й естрадного співу);

- інтеграція у процесі реалізації вищої музичної й музично-педагогічної освіти різних методичних систем, форм і методів навчання;

- збереження синкретизму китайського музично-вокального мистецтва, що об'єднує в собі музику, спів, сценічне мистецтво й поезію;

- забезпечення усвідомлення студентами того факту, що залучення школярів до вокальномузичного мистецтва вимагає приділення значної уваги формуванню в них духовності, естетичному й моральному вихованню особистості, розвитку її емоційної сорери $[1 ; 2 ; 4]$.

Лю Цзін також уточнює, що у процесі фрормування професійної компетентності майбутніх учителів музичного мистецтва значна увага приділяється опануванню ними таких професійно важливих груп методів та фрорм навчання:

- методами систематизації музичного матеріалу, активізації художньо-пізнавальної активності учнів, створення для них у соціальних мережах груп за музичними інтересами;

- фронаційно-ігровими вправами, зорієнтованими на вдосконалення вокальних навичок школярів, розвиток їхніх музичних здібностей, забезпечення усвідомлення музичних уявлень;

- рольовими іграми, що забезпечують психологічну й рухову розкутість людини, засвоєння нею рухово-танцювальних елементів, розвиток у школярів творчого уявлення, готовності до втілення музичного образу у своєму виконавському пісенному репертуарі;

- музичними сюжетно-рольовими іграми на виконання-спілкування, здійснення ритмо-рухових імпровізацій [3, с. 14].

Висновки. Отже, під час проведення наукових розвідок установлено, що у КНР накопичений цінний практичний досвід формування професійної компетентності майбутніх учителів музичного мистецтва. Також було визначено такі перспективні ідеї щодо творчого використання цього досвіду: забезпечення усвідомлення майбутніми вчителями музичного мистецтва своєї високої соціальної місії, що полягає в духовно-естетичному вихованні учнів та залученні їх до традиційної музичної культури свого народу; опанування майбутніми педагогів указаного профрілю засобів стилістичної комбінаторики, що розширює можливості виконавської діяльності школярів; організація під час проходження студентами соціально-педагогічної практики виконання ними різних видів (просвітня, навчальна, виконавська) суспільно корисної діяльності, зазвичай у віддалених бідних сільських районах.

У подальшому дослідженні планується виявити перспективні напрями творчого використання цінного практичного досвіду українських освітян із фрормування профресійної компетентності майбутніх учителів музичного мистецтва у вищій школі КНР.

\section{БІБЛІОГРАФІЧНИЙ СПИСОК:}

1. Ду Сывэй. Формирование певческих умений у вокалистов высших учебных заведениях КНР : дис. ... канд. пед. наук. Москва, 2008. 215 с.

2. Лі Данься. Формування виконавської культури майбутніх педагогів-музикантів України та Китаю у процесі фрортепіанної підготовки : автореср. дис. ... канд. пед. наук: 13.00.02. Київ, 2016. 20 с.

3. Лю Цзин. Развитие содержания профессиональной подготовки педагогов-музыкантов в Китае : автореф. .... канд. пед. наук: 13.00.02. 29 с.

4. Яо Вэй. Подготовка специалистов вокального искусства в системах высшего музыкального образования Китая и России : дис. ... канд. пед. наук: 13.00.01. Астрахань, 2015. 196 с.

5. 中華民國教師專業標準指引中華民國105 年2 月 15 日. 10 页.

6. 刘冬云. 艺术教育 : 未来的音乐老师不只是能弹会 唱_教学空间_中音在线. URL: http://www.musiceol.com/ news/html/2019-8/2019829129343315712.html. 